\title{
1201 適応信号処理アルゴリズムによる転がり軸受の音響診断技術
}

\section{Acoustic Diagnosis Technique for a Failure Rolling Bearing By Adaptive Signal Processing Algorithm}

\author{
○正太田博光 (水産大) 正瀬戸邦㴔（佐賀大）
}

Hiromitsu OHTA, Dept. of Ocean Mechanical Engineering, National Fisheries University, 2:7-1, Nagata-honmachi, Shimonoseki.

Kunisato SETO, Dept. of Mechanical Engineering, Saga University, 1, Honjo-machi,Saga.

Key Words: Acoustic, Diagnosis, Adaptive Signal Processing Algorithm, Adaptive Filter,RollingBearing

1. 緒 言

機械設備の異常診断では異常情報を得るために目的に匛じ たセンサが選択される. 回転機械の異常診断では一般的に SN 比の関係から圧電型加速度ビックアップが用いられているが診 断対象に設置する煩わしさや測定潆境によっては設置自体が困 難な場合が多々ある.これらを解消するために圧電型コンデン サマイクロホンを使用して非接独的に診断を行う力法があるが SN 比や外部騒音の問題があり実用的には今一歩である. 本研 究では適応信号処理法で用いられている適応フィルタににより 転がり軸受の音響診断を行っている. 固定されたフィルタ係数 を用いた音響喰断あってを診断対象の運転状態が定常的 もしくは運転パターンが把握できていれは診断精度の城少は少 ない. しかしながら予測不可能な非定常運転を行う設備を対象 とした診断には不向きである. 今回，適虑信号処理アルゴリズ ムとして勾配法に基づいて導出された LMS アルジリズム，適 応格子型(Gradient Adaptive Lattice)アルゴリズムおよび最小二 乗法に基づいた最小二乗格子型（Loast Squares Lattice)アルゴリ

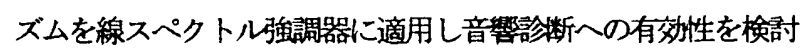
している. 検堼方法としては回転シミュレー夕に異常転がり軸 受を装着し単一コンデンサマイクロホンから得られた信号を DSP 上の各アルゴリズムのプログラムを実行し出力結果から得 られるSN比を比較し診断精度を検討している。

\section{2. 適念信号処理}

21 線スペクトル強調器線スペクトル強調器は適応信 号処理の基本的な問題の1つでありノイズに埋もれた信号を抽 出する手法として知られている.

$$
\begin{gathered}
\hat{x}_{t}=-\sum_{n=1}^{p} w_{n} x_{t-n} \\
x_{t}=s_{t}+n_{t}, e_{t}=x_{t}-\hat{x}_{t}
\end{gathered}
$$

ここで, $x_{t}:$ 測定される信号, $w_{n}:$ 次数 $n$ におけるフィルタ 保数, $\hat{x}_{t}$ : 予測される時系列, $s_{t}$ : 所望信号, $n_{t}$ : 定常白
色雑音, $e_{\boldsymbol{t}}$ : 予测就差. 適応信号処理では予測虽差を最小に する方向にフィルタ俰数が更新され所望信号が蚛調されノイズ

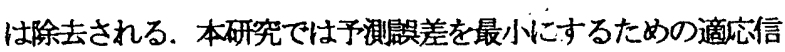
别処理アルゴリズムとして LMS アルゴリズム以下，LMS と 略. ), GAL アルゴリズム(GAL と略. )，LSL アルジリズム以 下，LSLと略.）を用いる。

\section{2 遥忥信号処理アルゴリズム}

・正規化USアルゴリスム＼cjkstart最急降下法の瞬时値を取った アルゴリスムが LMS であり、フィルタ俰数更新式は式(3)とな る. 式(4)の忘规係数を導入し収束特性を改善したものは正規化 LMSアルゴリズムと呼ばれる.

$$
\begin{aligned}
& \vec{w}_{t+1}=\vec{w}+\frac{2 \mu}{\sigma_{t}^{2}} \phi_{t} e_{t} \\
& \sigma_{t}^{2}=\lambda \sigma_{t-1}^{2}+(1-\lambda) x_{t}^{2}
\end{aligned}
$$

$\sigma_{t}^{2}$ : 信号 $x_{t}$ の分散, $\mu$ : 収束特性を決めるステップサイズ パラメータ, $\phi:$ フィルタ入カベクトル, $\lambda:$ 過去のデータ の影響を減衰させる忘却倸数。

・CAL アルゴリズムＩMS の収束特性はフィルタ入力ベ クトルの相関行列の条件数に依存している. この点を改良した のが GAL アルゴリズムである. 線スペクトル強調器では予測 誤差のみが必要である. 予測誤差の更新式は以下で表される.

$$
\begin{gathered}
f_{t}^{m+1}=f_{t}^{m}+\rho_{t}^{m+1} f_{t}^{m} \\
r_{t}^{m+1}=r_{t-1}^{m}+\rho_{t}^{m+1} f_{t}^{m} \\
\rho_{t+1}^{m+1}=\rho_{t}^{m+1}-\mu^{m+1}\left(f_{t}^{m+1} r_{t-1}^{m}+r_{t}^{m+1} f_{t}^{m}\right)
\end{gathered}
$$

$f_{t}^{m+1}:$ 前向き予測誤差, $r_{t}^{m+1}$ : 後向き予測誤差, $\rho_{t}^{m+1}$ : PAROOR倸数. 
・LSLアルゴリズム＼cjkstart勾配法に基づいたLMS、GALアルゴ リズムと異なり最小二乗法により導出されており一般的に収束 特性が傮九ている. 予測諟差の更新式を以下に示寸。

$$
\begin{aligned}
& \Delta_{N}^{m+1}=\lambda \Delta_{N-1}^{m+1}+f_{n}^{m} r_{N-1}^{m} / \theta_{N-1}^{m} \\
& F_{N}^{m+1}=F_{N}^{m}-\left(\Delta_{N}^{m+1}\right)^{2} / R_{N-1}^{m} \\
& R_{N}^{m+1}=R_{N-1}^{m}-\left(\Delta_{N}^{m+1}\right)^{2} / F_{N}^{m} \\
& \alpha_{N}^{m+1}=-\Delta_{N}^{m+1} / R_{N-1}^{m} \\
& \beta_{N}^{m+1}=-\Delta_{N}^{m+1} / F_{N}^{m} \\
& f_{N}^{m+1}=f_{N}^{m t}+\alpha_{N}^{m+1} r_{N-1}^{m} \\
& r_{N}^{m+1}=r_{N-1}^{m}+\beta_{N}^{m+1} f_{N}^{m} \\
& \theta_{N-1}^{m+1}=\theta_{N-1}^{m}-\left(r_{N-1}^{m}\right)^{2} / R_{N-1}^{m}
\end{aligned}
$$

$\Delta_{N}^{m+1}$ : 共分散, $F_{N}^{m+1}:$ 前向き残差分散, $R_{N-1}^{m}$ : 後乃 向き残差分散, $\alpha_{N}^{m+1}$ : 前向き PARCOR 係数, $\beta_{N}^{m+1}$ : 後向き PARCOR 係数.

\section{3. 実韭方法および結果}

夷験は外輪傷がある転がり軸受を回転シミュレー夕にセット し回転数 $1500 \mathrm{~mm}$ 一定て行った. 軸受から $50 \mathrm{~mm}$ の位置に 1 /4inch コンデンサマイクロホンを設置し測定を行っている. 各 アルゴリズムの有効生は TI 社の TMS32006711DSK をコンピ ニータでコントロールすることで検討している. 各アルゴリズ ムともカットオフ周波数は $3.2 \mathrm{kHz}$ である. LMS の遅延器数 5 ,

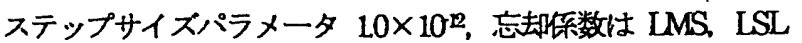
共に 0.995 とする. 図 1 はLMS およびLSLの収束特性を示し ている. 縦軸忏平均二乗誤差、横軸はフイルタ保数を更新する 際の計算回数を表している. 収束速度は LMSより LSLが優れ ており，平均二乗誤差に関しても LSL が少なく優れているこ とが分かる. 非定常な設備の診断に適用する場合は LSL が好 ましいと思われる. 図2は LMS, LSL を適応していない場合

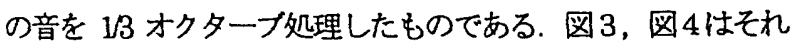
ぞれ LMS，LSL を適応し予測祦差(ノイズ)を除いた出力を $1 / 3$ オクターブ処理したものである. 適用しない場合オーバーオー M值で 220dB，LMS 適用で 180dB，LSL 適用で 176dBであり

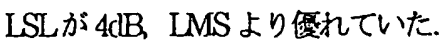

\section{4. 結言}

線スペクトル強調器による転がり軸受の音響診断を行った. 適応信号処理アルゴリズムとして正規化 LMS，GAL，LSLを 採用し診断精度の検討を行うた結果，収束特性は LSL が優机 ており，診断精度においても LSLが LMS よりも $4 \mathrm{~dB}$ 僋れて いることが判明した. また非定常運転を行う回転阵械の診断で は収束特性の良いLSLが好ましいと思われる。

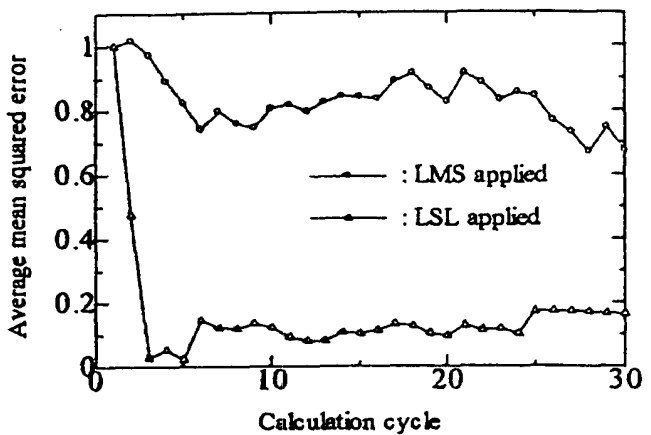

Fig 1 Convengene character of LMS and LSL algonithm (1)

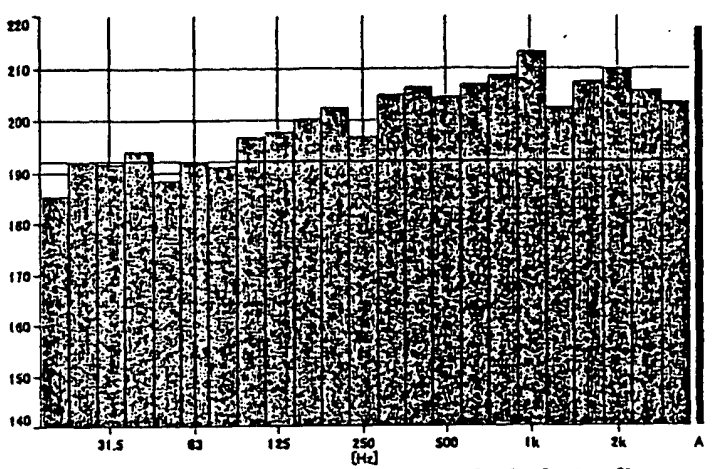

Fig2 1/3octave band analysis not applipdadptive filter

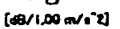

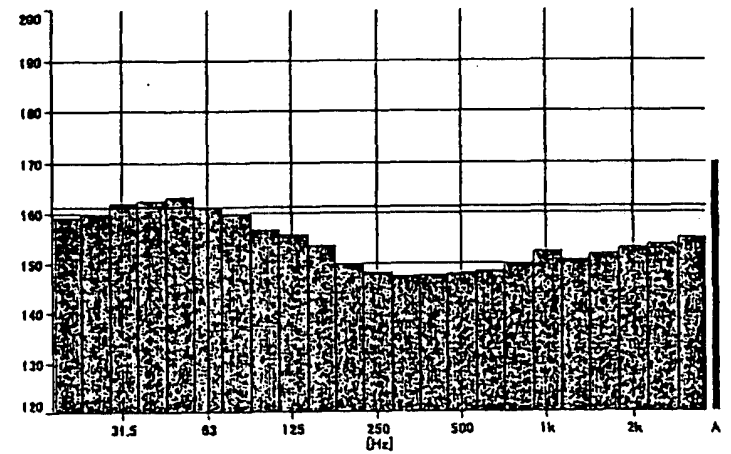

Fig3 1/3octave band analysis in the case of LMS algonithm

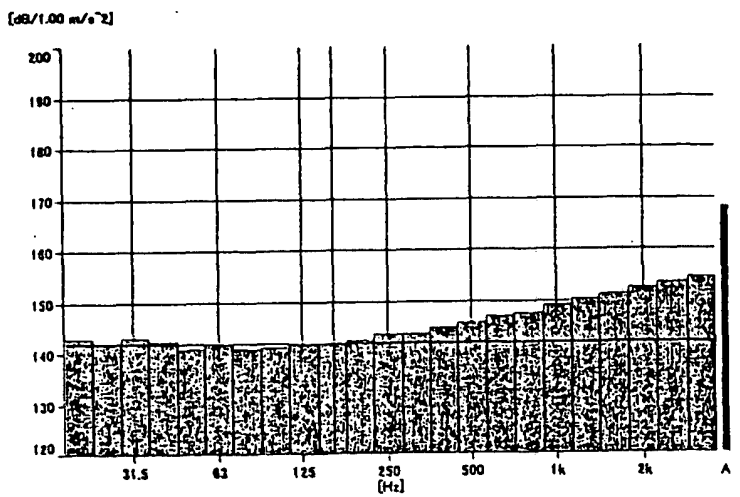

Fig4 1/3octave band analysis in the case of LSLalgonithm

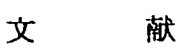

(1) 飯國群二，適応信号処理アルゴリズム，(2000，pp.1-100，pp.127149 , 培風管.

(2) Frrouitsu OHTAand Kunisuto SETO, "Acoustic Diagnosis ana Rolling Beaving Based on Presumption of a Division Term by Locally Stationany AR Mockd', Inter Noise2003, CDROM, N1025, 2003.

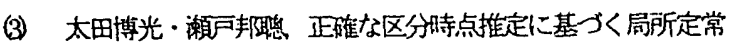

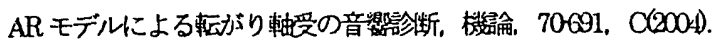

